\title{
Significance of Core Length in Current Transrectal Ultrasound-guided Prostate Biopsy in Patients with Normal Digital Rectal Examination
}

\author{
Normal Rektal Muayenesi Olan Hastalarda Transrektal Ultrason Eşliğinde Prostat \\ Biyopsisindeki Kor Uzunluğunun Önemi
}

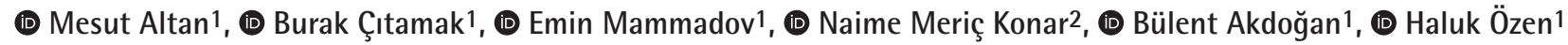 \\ 1 Hacettepe University Faculty of Medicine, Department of Urology, Ankara, Turkiye \\ 2 Hacettepe University Faculty of Medicine, Department of Biostatistics, Ankara, Turkiye
}

\section{What's known on the subject? and What does the study add?}

The core length is a significant quality indicator of $\mathrm{Bx}$, since it may define better sampling of prostate. However, there is still no cut-off value. Moreover, studies have involved heterogeneous patient groups, and have not focused on the patients with isolated PSA elevation.

\begin{abstract}
Objective: To reveal the significance of core length in current primary transrectal ultrasound-guided prostate biopsy (TRUS-PB) in patients with normal digital rectal examination.

Materials and Methods: Data of 3520 patients, who received TRUS-PB between March 2002 and April 2015, were reviewed retrospectively. A total of 1627 primary biopsy patients with a normal digital examination and with no lesion in TRUS were included in the study. The mean core length was found by dividing the sum of the total core lengths by the core number. The relationships of cancer detection rate (CDR) with age, Prostate-specific antigen (PSA) value, prostate volume, number of cores (10 or 12 cores) and mean core length were investigated.

Results: The mean patient age, PSA and prostate volume were $62.3 \pm 7.9$ years, $9.1 \pm 7.8 \mathrm{ng} / \mathrm{mL}$ and $55.8 \pm 21 \mathrm{~mL}$, respectively. Cancer was diagnosed

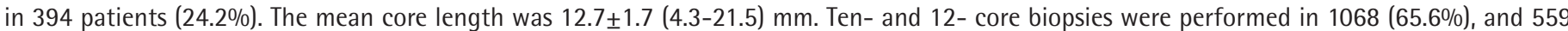
(34.4\%) patients, respectively. Older age, PSA, mean core length, number of cores and reduced prostate volume were found to be associated with $\operatorname{CDR}(p<0.001, p<0.001, p=0.006 p=0.043$, and $p<0.001$, respectively). In the multivariate analysis, age, PSA, prostate volume, mean core length, and number of cores were found to be independent factors in $\operatorname{CDR}(p<0.001, p<0.001, p<0.001, p=0.006$ and $p=0.009$, respectively).

Conclusion: Age, PSA, prostate volume, and number of cores, together with core length, are independent risk factors for cancer detection in TRUS$\mathrm{PB}$.
\end{abstract}

Keywords: Biopsy, Prostate cancer, Transrectal core biopsy

Öz

Amaç: Rektal prostat muayenesi normal olan ve Prostat spesifik antijen (PSA) yüksekliği nedeniyle transrektal ultrason eşliğinde iğne biyopsisi (TRUS-BX) yapılan hastalarda kor uzunluğunun prostat kanseri yakalama üzerindeki etkisini araştırmak.

Gereç ve Yöntem: Mart 2002 ile Nisan 2015 arasında TRUS-BX yapılan 3520 hastanın verileri retrospektif olarak analiz edildi. Rektal prostat muayenesi normal olan ve TRUS'da lezyonu olan 1627 hasta çalışmaya dahil edildi. Ortalama kor uzunluğu (OKU), toplam kor uzunluğunun alınan kor sayısına bölünmesiyle elde edildi. Yaş, PSA, prostat volümü, ortalama kor uzunluğu ve kor sayısının (10-12 kor) kanser yakalama üzerine etkisi araştırıldı.

Bulgular: Ortalama hasta yaşı, PSA ve prostat volümü sırasıyla $62,3 \pm 7,9$ yıl, 9,1 $\pm 7,8 \mathrm{ng} / \mathrm{mL}, 55,8 \pm 21 \mathrm{~mL}$ idi ve $394(\% 24,2)$ hastada kanser bulundu.

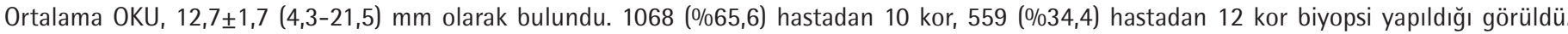
Yüksek yaş, PSA, ortalama kor uzunluğu, kor sayısı ve volümü ile kanser yakalama oranı arasında tek değişkenli analizde anlamlı ilişki bulundu. $(p<0,001, p<0,001, p=0,006 p=0,043$ ve $p<0,001$; sırasıyla). Çok değişkenli analizde artan yaş, PSA, ortalama kor uzunluğu, kor sayısı ve azalan

Correspondence: Mesut Altan MD, Hacettepe University Faculty of Medicine, Department of Urology, Ankara, Turkiye

E-mail: altanmst@gmail.com ORCID-ID: orcid.org/0000-0001-8884-9954

Received: 30.07.2019 Accepted: 06.12.2019

Cite this article as: Altan M, Çıtamak B, Mammadov E, Konar NM, Akdoğan B, Özen H. Significance of Core Length in Current Transrectal Ultrasound-guided Prostate Biopsy (Trus-Pb) in Patients With Normal Digital Rectal Examination. J Urol Surg 2020;7(2):83-87.

๑Copyright 2020 by the Association of Urological Surgery / Journal of Urological Surgery published by Galenos Publishing House. 
prostat volümü kanser yakalamak için bağımsız değişkenler olarak görüldü ( $p<0,001, p<0,001, p=0,006, p=0,009, p<0,001$; sırasıyla).

Sonuç: İzole PSA yüksekliği nedeniyle TRUS-BX yapılan hastalarda yaş, PSA, prostat volümü, kor sayısı ile birlikte kor uzunluğu da kanser yakalama oranını bağımsız olarak artırmaktadır.

Anahtar Kelimeler: Biyopsi, Kor uzunluğu, Prostat kanseri

\section{Introduction}

Transrectal ultrasound (TRUS)-guided prostate biopsy (PB) is currently the most valuable diagnostic tool for prostate cancer diagnosis. The cancer detection rate (CDR) ranges from $20 \%$ to $40 \%$ with the first PB (1). CDR depends on patientrelated factors, such as patient age, prostate-specific antigen (PSA) level, prostate volume, as well as number of cores and transportation mode of the pathology specimens. Besides, the experience of the urologist and pathologist has paramount importance $(2,3,4,5)$. Recently, a number of studies on core length have remarkably increased. Core length is a significant quality indicator of $\mathrm{PB}$, since it may define better sampling of the prostate $(2,3)$. However, there is still no cut-off value. Moreover, studies have involved heterogeneous patient groups, and have not focused on patients with isolated PSA elevation. In this study, patient-related parameters, such as age, PSA level and prostate volume were investigated together with the effect of core length on CDR in patients with isolated PSA undergoing TRUS-PB.

\section{Materials and Methods}

\section{Ethics Statement}

The Institutional Review Board of Hacettepe University Hospital approved this study (approval number: G0 18/74606). The need for informed consent from patients was waived by the Institutional Review Board because this study was a retrospective analysis. The records and information of patients were anonymized and de-identified prior to analysis.

\section{Patient Population}

Data of 3520 patients who had undergone TRUS-PB between March 2002 and April 2015 were retrospectively investigated. Patients with an abnormal digital rectal examination (DRE) or with TRUS lesions were excluded. The data of 1627 primary biopsy patients with isolated PSA elevation were investigated.

\section{TRUS-guided Biopsy and Pathologic Examination}

All patients were subjected to antibiotic prophylaxis before the procedure. The same US device (BK US ${ }^{\circledR}$ ) and 18-gauge biopsy gun (Pro-Mag ${ }^{\mathrm{TM}}$ ) were used in all patients. Prostate volume was calculated by measuring three dimensions of the prostate in all patients. Before performing the biopsy, all patients were administered periprostatic nerve block by using $2 \%$ prilocaine.
Ten- or 12-core biopsies were taken in the lateral decubitus position. All biopsies were separately placed into the tubes containing 10\% formaldehyde, and they were sent to the laboratory to be examined by the uropathologists, together with the records of the location of the biopsy. The tissues were analyzed by uropathologists; the measurements and pathological results of all cores were written in the pathology report.

\section{Examination of Factors}

Age, PSA level, number, and length of all biopsied cores were recorded for all patients. Patients with atypical small acinar proliferation (ASAP) and high-grade prostatic intraepithelial neoplasia (HGPIN) were not included in the cancer group. The mean core length was calculated by dividing the sum of core lengths by the number of cores. The relationships between age, PSA level, prostate volume, mean core length, and core number were analyzed in patients in whom cancer was detected. The mean core length at the base, mid and apex of the prostate were compared. Also, the relationship between each core length and CDR was investigated.

\section{Statistical Analysis}

All the analyses were done by using the SPSS version 23.0 (IBM Corp. Released 2015. IBM SPSS Statistics for Windows, version 23.0. Armonk, NY: IBM Corp.). Student's t-test and analysis of variance (ANOVA) were used for normally distributed variables, while the Mann-Whitney $U$ test was used for non-normally distributed variables. Chi-square test was used to evaluate the categorical variables. In multivariate analysis, binary logistic regression analysis was used together with receiver operating characteristic (ROC) analysis to obtain the cut-off value. A p value of less than 0.05 was considered statistically significant in all analyses.

\section{Results}

A total of 1627 primary biopsy patients with a normal digital examination and with no lesion in TRUS were included in the study. The mean patient age, PSA level, and prostate volume were $62.3 \pm 7.9$ years, $9.1 \pm 7.8 \mathrm{ng} / \mathrm{mL}$ and $55.8 \pm 21 \mathrm{~mL}$, respectively. Cancer was detected in 394 patients $(24.2 \%)$. The calculated mean core length was $12.7 \pm 1.7$ (range: 4.3-21.5) $\mathrm{mm}$. 10- and 12-core biopsies were performed in 1068 (65.6\%), and 559 (34.4\%) patients, respectively. 
Univariate analysis revealed that patients with cancer had older age, higher PSA level and higher mean core length $(p<0.001$, $p<0.001$ and $p=0.006$, respectively), whereas smaller mean prostate volume $(p<0.001)$. The 12 -core group had a significantly higher CDR compared to the 10-core group $(p=0.043)$ (Table 1). Multivariate analysis revealed that age, PSA level, mean core length, prostate volume and number of cores were found to be independent factors in the CDR $(p<0.001, p<0.001, p=0.006$, $p<0.001$ and $p=0.009$, respectively) (Table 2 ).

Cancer was detected in 1.723 of 17.388 cores $(7.6 \%)$. The mean core length was $12.80 \pm 3.2(1-35) \mathrm{mm}$. The mean length of the cores with and without cancer was $13.46 \pm 3.1 \mathrm{~mm}$ and $12.73 \pm 3.2 \mathrm{~mm}$, respectively $(p<0.001)$. When the ROC analysis was performed, the threshold value was determined to be 13 $\mathrm{mm}$ with $55.5 \%$ sensitivity and 50.7\% specificity (AUC: 0.555 , $p<0.001$ ) (Figure 1).

Table 1. The results of univariate analysis of the variables (age, Prostate-specific antigen level, prostate volume, cores, and core length)

\begin{tabular}{|c|c|c|c|c|}
\hline \multirow{2}{*}{\multicolumn{2}{|c|}{ Age, year (mean $\pm S D)$}} & Cancer & No cancer & p \\
\hline & & $65.4 \pm 7.3$ & $61.3 \pm 8.7$ & $<0.01^{*}$ \\
\hline \multicolumn{2}{|c|}{$\mathrm{PSA}, \mathrm{ng} / \mathrm{mL}($ mean $\pm \mathrm{SD})$} & $11.3 \pm 10.8$ & $8.3 \pm 6.4$ & $<0.01^{* *}$ \\
\hline \multicolumn{2}{|c|}{ Volume, $\mathrm{mL}$ (mean $\pm \mathrm{SD}$ ) } & $58.5 \pm 20$ & $46.9 \pm 21.3$ & $<0.01^{* *}$ \\
\hline \multicolumn{2}{|c|}{$\begin{array}{l}\text { Mean core length, } \mathrm{mm} \\
\text { (mean } \pm \mathrm{SD})\end{array}$} & $12.96 \pm 1.5$ & $12.64 \pm 1.8$ & $0.006^{* *}$ \\
\hline \multirow{2}{*}{ Core number } & 10 cores & $22.7 \%$ & $77.3 \%$ & \multirow{2}{*}{$0.043^{* * *}$} \\
\hline & 12 cores & $27.2 \%$ & $72.8 \%$ & \\
\hline
\end{tabular}

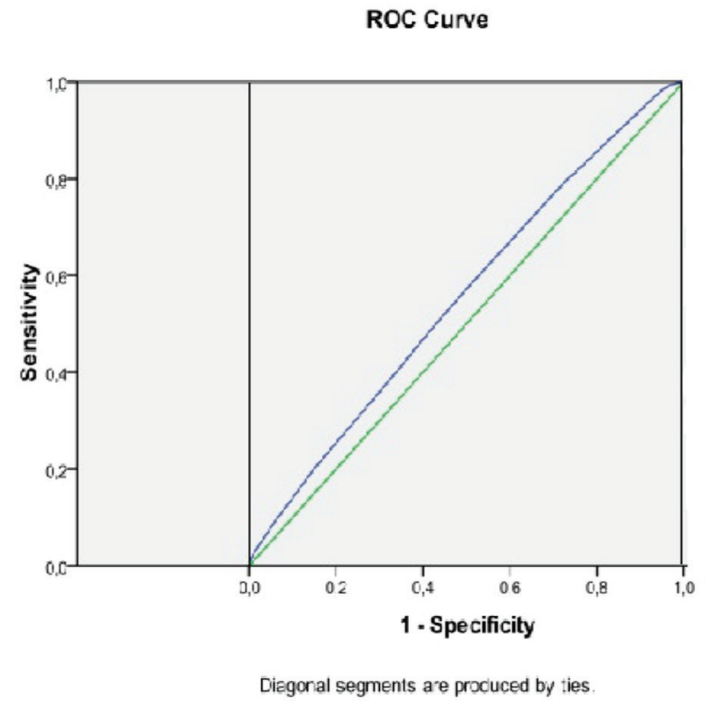

Figure 1. Receiver operating characteristic analysis curve of cancer detection with core lengths of 17.146 cores, AUC: $0.555(p<0.001)$
The core lengths were compared regarding the base, mid, and apex locations. It was found that the core length at the base was significantly higher compared to that at the mid and apex $(p<0.001, p<0.001$, respectively) and the core length at the midprostate was higher than at the apex $(p<0.001)$. The lengths of the cores at the base, mid and apex of the prostate were determined to be higher in the group with cancer ( $p=0.014$ $p=0.046$ and $p=0.016$, respectively) (Table 3 ).

\section{Discussion}

TRUS-PB has an obvious role in the diagnosis of prostate cancer and has continued to increase its diagnostic efficacy in recent years as well. Systematic sextant PB procedure was introduced to clinical use in 1989 and has been improved over the years. One of the most important steps in increasing CDR was increasing the number of biopsy cores shown by many authors $(4,6)$. Similarly, others demonstrated a significant increase in CDR by laterally directed cores $(7,8)$.

There were some debates about how many core biopsies should be obtained until recent years, biopsy up to the 10-12 cores became standard since it significantly increased the CDR without increasing side effects. Although there were no significant differences regarding the CDR between 12-core, 18-core, and 24-core biopsy methods, the side effects were increased with the increasing number of cores (9). In our study, the CDR was significantly higher in the systematic 12-core biopsy compared to the 10-core biopsy.

Another important issue is sampling of all prostatic regions equally. In particular, the transperineal approach comes to the forefront regarding the sampling of the apex $(10,11)$. The efficacy of the transperineal approach in detecting prostate cancer compared to the transrectal approach is another debate. Some studies revealed increased CDR without increasing complications by transperineal whereas others demonstrated similar CDR and complication rates $(12,13,14)$. Although officebased transperineal PB with epidural anesthesia is an important diagnostic method, the transrectal approach maintains its place as an important diagnostic method due to ease of its use together with the current experience of urologists.

Table 2. The results of multivariate analysis of parameters in detecting prostate cancer

\begin{tabular}{|l|l|l|l|}
\hline Parameters & $\mathbf{p}$ & Odds Ratio (OR) & $\mathbf{9 5 \%} \mathrm{Cl}$ \\
\hline Age, year & $<0.001$ & 1.049 & $1.04-1.08$ \\
\hline PSA, ng/mL & $<0.001$ & 1.105 & $1.07-1.13$ \\
\hline Volume, $\mathbf{m L}$ & $<0.001$ & 0.937 & $0.92-0.94$ \\
\hline Core length, mm & 0.006 & 1.116 & $1.03-1.20$ \\
\hline Core number, 12 cores & 0.009 & 1.210 & $1.04-1.39$ \\
\hline PSA: Prostate-specific antigen, Cl: Confidence interval \\
\hline
\end{tabular}


Table 3. Comparison of total core length of base, mid, and apex, cancerous and noncancerous localizations

\begin{tabular}{|c|c|c|c|c|c|c|c|}
\hline \multirow{2}{*}{\multicolumn{2}{|c|}{ Parameters }} & \multicolumn{6}{|l|}{ Site } \\
\hline & & \multirow{2}{*}{$\begin{array}{l}\text { Base } \\
13(1-25)\end{array}$} & \multirow{2}{*}{\begin{tabular}{|l}
$\mathbf{p}$ \\
$0.014^{*}$
\end{tabular}} & \multirow{2}{*}{$\begin{array}{l}\text { Mid } \\
12(1-25) \\
13(2-24)\end{array}$} & \multirow{2}{*}{$\begin{array}{l}\mathbf{p} \\
0.046^{*}\end{array}$} & \multirow{2}{*}{$\begin{array}{l}\text { Apex } \\
11(1-24) \\
12(9-22)\end{array}$} & \multirow{2}{*}{$\begin{array}{l}\mathbf{p} \\
0.016^{*}\end{array}$} \\
\hline Cancer & Absent, $\mathrm{mm}$ & & & & & & \\
\hline \multicolumn{2}{|c|}{ Mean core length, $\mathrm{mm}$} & $13.3 \pm 3$ & $<0.001^{* *}$ & $12.8 \pm 3.1$ & $<0.001^{* *}$ & $11.8 \pm 3.5$ & $<0.001^{* *}$ \\
\hline
\end{tabular}

The optimum sampling of the prostatic apex is an important issue since urologists may face some difficulties in performing ideally. Iczkowski et al. (15) showed that the cores from the prostatic base and the mid had higher core lengths compared to the apex, and the core length was a significant variable for CDR at the apex. They also identified that the longest cores were caught from the base and the shortest from the apex. We suggest that the most probable reason for obtaining shorter cores from the apex is technical difficulties. Urologists need to be more cautious to sample apex better.

In our study, PSA was found to be an independent variable increasing CDR. Moreover, patients with smaller prostate had cancer more commonly. A possible explanation is our exclusion criteria; patients with a palpable nodule were excluded in our study, only patients with an elevated PSA were included. Increased PSA value per unit tissue and increased sampling ratio to the total prostate volume might explain increased CDR in smaller size prostates.

Core length is a significant parameter regarding the quality of PB. The importance of core length in CDR is controversial and there is insufficient data in studies $(16,17,18)$. In a study including 3.479 patients, the core length in patients diagnosed with and without cancer was not different $(16.1 \pm 1.8$ vs. $16.1 \pm 1.9$ $m m$, respectively, $p=0.945)$, (5). The authors suggested that this result might be due to the core lengths being so close to each other. Moreover, in the same study, when the core number was also considered to have no effect on CDR, it might be suggested that the inclusion of abnormal digital rectal examination (DRE) findings and suspicious lesion on TRUS in the patient population might also be a cause.

The cut-off value for the core length in cancer detection was $11.9 \mathrm{~mm}$ in a series involving 331 patients (17). The cancer rates in patients with the core lengths below and above this value were $23 \%$ and $39 \%$, respectively. On the other hand, the researchers found that upgrading was increased in patients with short core lengths when they compared the core length to the final pathologies of the patients who had undergone radical prostatectomy (18). In our study, the core length in patients with cancer was significantly higher than in patients without cancer. In multivariate analysis, higher core length was independently associated with CDR. In our study, to make a more homogenous patient cohort, the patients with abnormal DRE findings and patients with TRUS lesions were excluded.

In our study, the cut-off value was found to be $13 \mathrm{~mm}$ by evaluating 17.388 cores. The sensitivity and specificity were $55.5 \%$ and $50.7 \%$, respectively. The sensitivity and specificity may be thought not high values, but increasing core length or core number will not increase the CDR in prostates without cancer. If we consider that most of the patients and cores did not have cancer in this study, the absence of cancer in the long cores obtained from these areas may hide the importance of the increased core length and CDR in cancerous locations of cancerous prostates. Another important point is ignorance of important parameters such as PSA level and age during a core-based evaluation. For example, when a patient with a low PSA level was compared to another patient with a high PSA level, both having similar core lengths, the mean core length measured for each patient can be a more significant parameter. We suggest that increased core length, together with an increased number of cores, will enhance the biopsy quality by allowing sampling of the prostate more efficiently.

The most significant limitation of this study was its retrospective design. Conducting the study in a research hospital, physicians having different levels of biopsy experience and a study period of 13 years can be considered other limitations of the study. To involve patients with ASAP and HGPIN in the study is a limitation; however, these two parameters did not take place in our data. The absence of biopsy complications in the present data has prevented the investigation of the relationship between the effects of cancer detection and the complications.

\section{Conclusion}

Increased age, PSA level, and reduced prostate volume, together with increased core length, are independent factors for detecting cancer in patients undergoing TRUS-PB due to isolated PSA elevation. Increased core length is an essential parameter of biopsy quality by increasing the CDR.

\section{Ethics}

Ethics Committee Approval: The Institutional Review Board of Hacettepe University Hospital approved this study (approval number: G0 18/746-06). 
Informed Consent: The need for informed consent from patients was waived by the Institutional Review Board because this study was a retrospective analysis.

Peer-review: Externally and internally peer-reviewed.

\section{Authorship Contributions}

Concept: M.A., Design: B.A., Data Collection or Processing: M.A., E.M., B.Ç., Analysis or Interpretation: N.M.K., Literature Search: M.A., E.M., B.Ç., Writing: M.A., E.M., B.Ç.

Conflict of Interest: No conflict of interest was declared by the authors.

Financial Disclosure: The authors declare that they have no relevant financial disclosure.

\section{References}

1. Chun FK, Epstein Jl, Ficarra V, Freedland SJ, Montironi R, Montorsi F, Shariat SF, Schröder FH, Scattoni V. Optimizing performance and interpretation of prostate biopsy: a critical analysis of the literature. European urology. 2010;58:851-864

2. Boccon-Gibod L, van der Kwast TH, Montironi R, Boccon-Gibod L, Bono A. Handling and pathology reporting of prostate biopsies. European urology. 2004;46:177-181.

3. van der Kwast TH, Lopes C, Santonja C, Pihl CG, Neetens I, Martikainen P, Di Lollo S, Bubendorf L, Hoedemaeker RF; Members of the pathology committee of the European Randomised Study of Screening for Prostate Cancer. Guidelines for processing and reporting of prostatic needle biopsies J Clin Pathol. 2003;56:336-340.

4. Guichard G, Larre $S$, Gallina A, Lazar A, Faucon $H$, Chemama $S$, Allory $Y_{1}$ Patard J-J, Vordos D, Hoznek A, Yiou R, Salomon L, Abbou CC, de la Taille A. Extended 21-sample needle biopsy protocol for diagnosis of prostate cancer in 1000 consecutive patients. European urology. 2007;52:430-435.

5. Lee S, Jeong SJ, Hwang SI, Hong SK, Lee HJ, Byun SS, Choe G, Lee SE. Clinical value of core length in contemporary multicore prostate biopsy. PloS one 2015; 10:e123704
6. Shariat SF, Roehrborn CG. Using biopsy to detect prostate cancer. Rev urol. 2008:10:262-280.

7. Chang JJ, Shinohara K, Bhargava V, Presti JC, Jr. Prospective evaluation of lateral biopsies of the peripheral zone for prostate cancer detection. The Journal of urology. 1998;160:2111-2114.

8. Epstein Jl, Walsh PC, Carter HB. Importance of posterolateral needle biopsies in the detection of prostate cancer. Urology. 2001;57:1112-1116.

9. Eichler K, Hempel S, Wilby J, Myers L, Bachmann LM, Kleijnen J. Diagnostic value of systematic biopsy methods in the investigation of prostate cancer: a systematic review. J Urol. 2006;175:1605-1612.

10. Satoh T, Matsumoto K, Fujita T, Tabata K, Okusa H, Tsuboi T, Arakawa T, Irie $A$, Egawa $S$, Baba $S$. Cancer core distribution in patients diagnosed by extended transperineal prostate biopsy. Urology. 2005;66:114-118.

11. Ficarra V, Martignoni G, Novella G, Cerruto MA, Galfano A, Novara G, Pea $M$, Artibani $W$. Needle core length is a quality indicator of systematic transperineal prostate biopsy. European urology. 2006;50:266-271.

12. Emiliozzi P, Corsetti A, Tassi B, Federico G, Martini M, Pansadoro V. Best approach for prostate cancer detection: a prospective study on transperineal versus transrectal six-core prostate biopsy. Urology. 2003;61:961-966.

13. Hara $R$, Jo $Y$, Fujii $T$, Kondo N, Yokoyoma T, Miyaji $Y$, Nagai A. Optimal approach for prostate cancer detection as initial biopsy: prospective randomized study comparing transperineal versus transrectal systematic 12-core biopsy. Urology. 2008;71:191-195.

14. Merrick GS, Irvin S, Fiano R, Anderson R, Butler WM, Adamovich E. Pathology and Quality of Life Outcomes Following Office-based Transperineal Prostate Biopsy. Urology 2016;94:24-28.

15. Iczkowski KA, Casella G, Seppala RJ, Jones GL, Mishler BA, Qian J, Bostwick DG. Needle core length in sextant biopsy influences prostate cancer detection rate. Urology. 2002;59:698-703.

16. Fiset PO, Aprikian A, Brimo F. Length of prostate biopsy cores: does it impact cancer detection? The Can J Urol. 2013;20:6848-6853.

17. Obek C, Doganca T, Erdal S, Erdogan S, Durak H. Core length in prostate biopsy: size matters. J Urol. 2012;187:2051-2055.

18. Reis LO, Sanches BC, de Mendonca GB, Silva DM, Aguiar T, Menezes OP, Billis A. Gleason underestimation is predicted by prostate biopsy core length. World J Urol. 2015;33:821-826. 